\title{
Stemflow Variability in Tropical Lowland Forest Landscape Transformation System: Case Study at Jambi Province, Indonesia
}

\author{
Bejo Slamet ${ }^{1,2^{*}}$, I Nengah Surati Jaya ${ }^{3}$, Hendrayanto ${ }^{3}$, Suria Darma Tarigan ${ }^{4}$
}

\author{
${ }^{1}$ Graduate School of Bogor Agricultural University, Dramaga Main Road, Campus IPB Dramaga, Bogor, Indonesia 16680 \\ ${ }^{2}$ Department of Forestry, Faculty of Agriculture, Sumatera Utara University, Medan, Indonesia 20155 \\ ${ }^{3}$ Department of Forest Management, Faculty of Forestry, Bogor Agricultural University, Academic Ring Road, Campus IPB \\ Dramaga, PO Box 168, Bogor, Indonesia 16680
}

${ }^{4}$ Department of Soil and Natural Resources Management, Faculty of Agriculture, Bogor Agricultural University, Academic Ring Road, Campus IPB Dramaga, Bogor, Indonesia 16680

Received March 2, 2015/Accepted April 19, 2015

\begin{abstract}
Land cover change may cause change on the hydrological function of an area, particularly on the distribution of rainfall that reach land surface. This study describes the characteristic of stemflow occurred within 4 ecosystems in Jambi, namely logged forest, jungle rubber, rubber plantation, and oil palm plantation. The main objective of the study was to measure the variability of stemflow in those 4 ecosystems. The main data used were rainfall and stemflow data that were directly measured for 5 months. The derived regression equation model showed that stemflow increase with rainfall depth. It was shown that values of stemflow amongs plantation types was varied indicated by the difference of its regression coefficients, as well as variations of the rainfall at the same transformation type. The percentage of stemflow to rainfall was ranging from $0.04-0.21 \%$ for rubber, $0.10-0.38 \%$ for jungle rubber, 0.28-0.54\% for forest, and 0.84-3.07\% for oil palm. The oil palm provided the highest stemflow volume compared to other land cover type. The uniqueness of oil palm canopy may cause the drainage of water from the canopy to the main stem that indicated by highest stemflow funneling ratio value. Rainfall significantly affected the amount of stemflow compared with the characteristics of the plant.
\end{abstract}

Keywords: forest transformation, land cover change, stemflow variability, stemflow funnelling ratio

*Correspondenceauthor, email:bejoslam@gmail.com, tel.: +62-61-8201920

\section{Introduction}

Conversion of forests into other land uses has become a major issue in Indonesia, which causes a decline in forest cover (Romijn et al. 2013), especially natural forests on Sumatra Island, which is converted into oil palm plantations (Broich et al. 2011) and rubber plantations (Miyamoto 2006). During the past 10 years, oil palm plantations in Indonesia has doubled from 4.16 million ha in 2000 to 8.25 million ha in 2009 , as well as the extensive rubber plantations during this period has increased by 62,849 ha from area $3,372,421$ ha in 2000 to 3,435,270 ha in 2009 (MoA 2012). The decline of forest area and the increase of plantation area indicate a change in the water balance of the ecosystem (Nieschulze et al. 2009; Zhang et al. 2012; Dasanto et al. 2014). Land cover changes result in vegetation structure changes which affects the redistribution of rainfall through the soil surface (Zimmermann et al. 2008). The rain that falls on the vegetation will be retained by the plant canopy for a specific period. Most of this water evaporates and other reaches the ground because of dripping through the plant canopy or flowing down through the stem until reaching the base of the plant as stemflow. Part of rainfall that reaching at the ground level is the sums of the throughfall and stemflow. Throughfall and stemflow controlled the distribution of rainfall that reach the ground level (Germer et al. 2010). Thus, the distribution of rainfall that goes into the ground is uneven. Past research has shown that stemflow gives high spatial variability (He et al. 2014), among species (Levia et al. 2010), vegetation communities (Carlyle-Moses et al. 2004; Bryant et al. 2005; Germer et al. 2006; Ziegler et al. 2009; Bäse et al. 2012), and regions (Komatsu et al. 2008).

The rainfall distribution pattern as throughfall and stemflow affects the amount of water that may be infiltrated into soil (Shachnovich et al. 2008). Previous researches had been conducted in tropical mountain forests to identify the magnitude and variability of stemflow among some trees species (Herwitz 1986), the stem influence to the stemflow (Park \& Cameron 2008), relationship between stemflow, and tree characteristics (Uber et al. 2014), the relationship among stemflow, rainfall, antecedent dry period, and area of stem bark (Hofhansl et al. 2012). Other researchers focus on the study of variability of stemflow with certain types of species (Opakunle 1989; Park \& Cameron 2008; Siles et al. 2010). Although research on the interception and its parameters has 
been done for decades, but its relationship with the vegetation has not fully understood yet (Dietz et al. 2006). Research on stemflow variability in landscape transformation of tropical lowland rainforest represented by logged forest, jungle rubber, rubber plantation, and oil palm plantation has not been done. The purpose of this study was to examine the stemflow variability of 4 land cover types of tropical lowland rainforest landscape transformation system namely logged forest, jungle rubber, rubber plantation, and oil palm plantation.

\section{Methods}

Description of study site This research was conducted at 4 types of land covers namely logged forest, jungle rubber, rubber plantation, and oil palm plantation. The sites of the study were administratively located in the of Bungku Village, Bajubang District, Batanghari Regency, Jambi Province. It is geographically located at coordinates E103 $16^{\prime} 1.2^{\prime \prime}$ to $\mathrm{E} 103^{\circ} 16^{\prime} 19.2^{\prime \prime}$ and $\mathrm{S} 1^{\circ} 54^{\prime} 28,8^{\prime \prime}$ to $\mathrm{S} 1^{\circ} 54^{\prime} 43.2^{\prime \prime}$. The locations were $50-100 \mathrm{~m}$ asl.

Research plot for forest cover was logged forest. Research plot for jungle rubber was the rubber trees planted by community in 1986 and then left without any management. Research plot for rubber plantation was monoculture rubber plantation planted by people in 1999 and carried out an intensive tapping once every 2 days. The research plots for oil palm plantation were monoculture oil palm plantation planted by community in 1999 (aged 14 years) and in 2005 (aged 8 years). Annual rainfall during the period 2001-2012 which were measured in the oil palm plantation of PT Asiatic Persada showed that annual rainfalls ranged 2,154-3,451 $\mathrm{mm}$, with average of 2,475 $\mathrm{mm}_{\text {year }}{ }^{-1}$. The mean of annual rainy days in the study area was 128 days (PT Asiatic Persada 2013).

Variability of stemflow was obtained by analyzing the parameters of stemflow. The parameters of stem flow calculation were:

1 Stemflow yield (Sy), of which stemflow volume deposited in a container $(\ell)$ (Germer et al. 2010).

2 Stemflow depth $(\mathrm{Sd})$, which was defined as stemflow per area of collectors (mm). The stemflow depth (Germer et al. 2010) is formulated in Equation [1]:

$\mathrm{Sd}=\mathrm{Sy} / \mathrm{A}$

note:

$\mathrm{Sd}=$ stemflow depth $(\mathrm{mm})$

Sy $=$ stemflow volume $(\ell)$

$\mathrm{A}=$ canopy area projection $\left(\mathrm{m}^{2}\right)$

3 Stemflow rate $(\mathrm{Sr})$, stemflow rate indicates the volume of rainfall reaching the soil surface through stemflow per mm of rainfall, calculated using Equation [2] (Germer et al.2010):

$\mathrm{Sr}=\mathrm{Sy} / \mathrm{R}$

note:

$\mathrm{Sr}=$ stemflow rate $\left(\ell \mathrm{mm}^{-1}\right)$

Sy $=$ stemflow volume $(\ell)$

$\mathrm{R}=$ rainfall depth $(\mathrm{mm})$.

4 Stemflow funneling ratio (SFR), which according to Herwitz (1986) is defined as the flow-per-square rod collector normalized using rainfall depth (dimensionless), calculated by Equation [3]:

$\mathrm{SFR}=\mathrm{Sy} / \mathrm{RB}$

note:

SFR $=$ stemflow funneling ratio

Sy $=$ stemflow volume $(\ell)$

$\mathrm{R} \quad=$ rainfall depth $(\mathrm{mm})$

$\mathrm{B}=$ stem basal area $\left(\mathrm{m}^{2}\right)$

The SFR shows the ratio between the volume of rainfall that flows into the base of the plant or tree trunks at certain diameter and the volume of rainfall that captured by the equal diameter rain gauge placed in an open area. SFR measures the impact of specific vegetation on redistribution and accumulation of rainfall (Garcia-Estringana et al.2010).

Stemflow measurements were carried out in November 2012 to March 2013. Measurements were performed on 4 plants of oil palm (Elaeis guineensis Jacq.) in oil palm plantations namely OP1, OP2, OP3, and OP4, 6 sample trees in the rubber plantation namely R1, R2, R3, R4, R5 (Hevea braziliensis), and R6 (Archidendron pauciflorum), 2 sample trees in the jungle rubber namely JR1 (Hevea braziliensis) and JR2 (Macaranga sp.), and 2 trees in the logged forest namely F1 and F2 (Litsea sp.). The stemflow measurement was done every rainy day. Tools to measure the stemflow of oil palm were zincs plate that was inserted into the palm fronds and sealed with silicone to prevent leaks. After zincs plate was inserted properly on the oil palm trunks, the bottoms side then was connected to a jerry can containers which are made by using multi-slot diviser method. The first container is given 11 holes and one of them was connected to the second jerry can so that the total capacity reaches $288 \ell$. Stemflow measurements on sample trees in the logged forest, jungle rubber, and rubber plantation were conducted by strapping a plastic hose which had been split and then nailed to the trunk to be stuck. Affixed hose was then sealed with a smooth silicone on its stick to prevent leakage. Finally, at the bottom of the hose was connected to the jerry can containers. Installation of stemflow measurement tool is shown in Figure 1.

Rainfall measurement was done every day by using Ombrometer Rainfall Gauge having a diameter of $14 \mathrm{~cm}$. Two rainfall gauges were placed in an open area around the plot of stemflow measurements and another one was placed above the canopy of oil palm with a height of $6 \mathrm{~m}$ above ground level. Rainfall data of rainfall gauges in 3 locations were then averaged. Minimum daily rainfall used in the analysis was the depth of $0.5 \mathrm{~mm}$. Stand structure variables such as basal area and stand density was obtained by performing an inventory of vegetation in the plot.

Data analysis Data were analyzed descriptively by taking into account of measurement results in the field. Descriptive statistical analysis was done to see the average and standard deviation of each of analyzed stemflow parameter. Paired ttest was conducted to analysis the differences of each stemflow parameter. The relationship between the rainfall depth and the stemflow depth was analyzed by making a regression equation in which the stemflow depth was independent variable and the rainfall depth was dependent variable. 

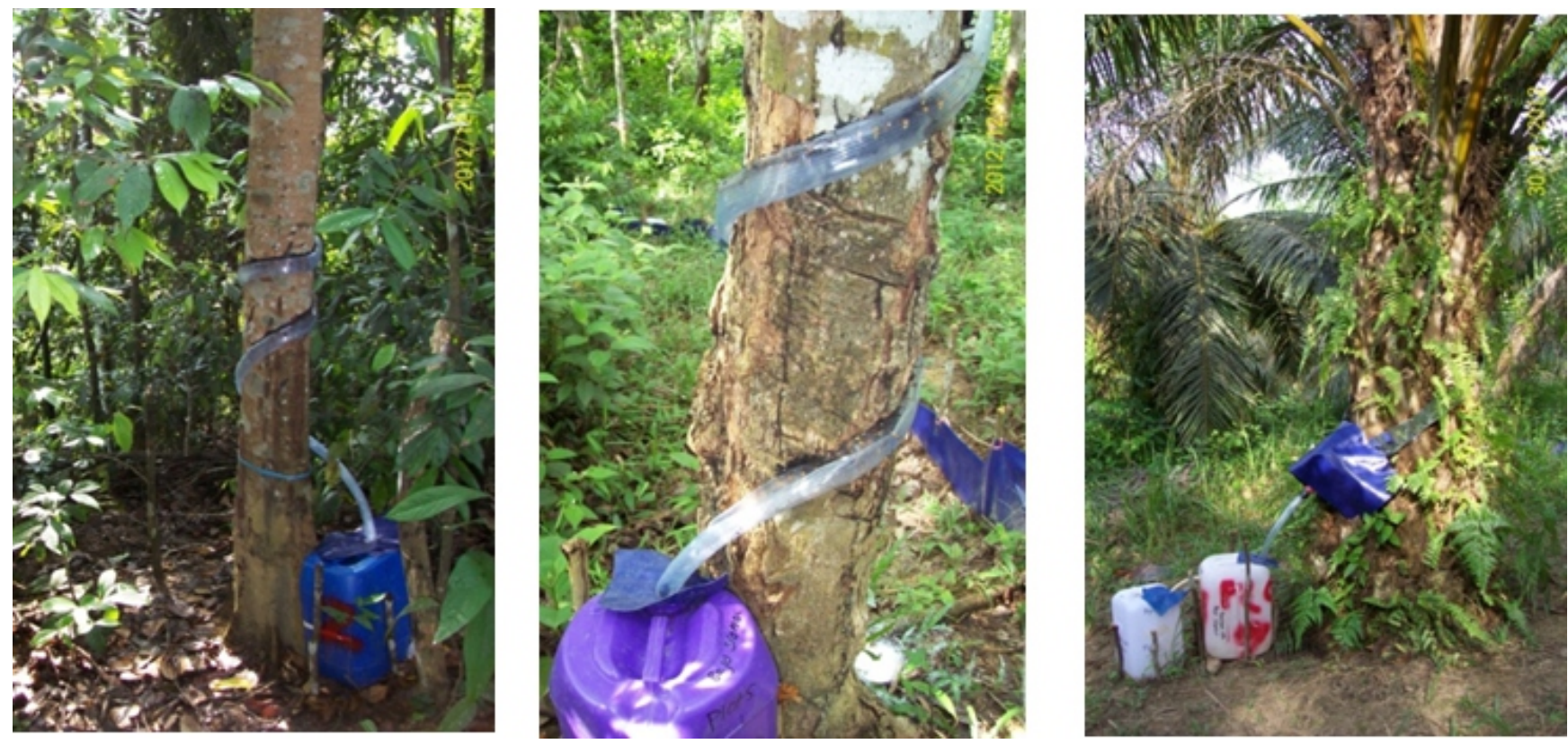

Figure 1 Setting up the measurement tool of stemflow volume.

\section{Results and Discussion}

Daily rainfall Rainfall measurement results for 5 months provided the number of rainy days recorded as many as 75 days of rainy days, with daily rainfall interval range was 0.56-78.69 $\mathrm{mm}$. Mean of daily rainfall during the study amounted to $18.40 \pm 21.40 \mathrm{~mm}$. Figure 2 shows that the rainfall was concentrated in less than $10 \mathrm{~mm}$ of daily rainfall. The results of the standard deviation calculation of daily rainfall measurements suggests that the daily rainfall data has a very high variability.

Stemflow yield Stemflow volume measured varies both on the same and the difference of land cover types. The stemflow volume (liter) and its relationship with rainfall depth for each plant of any measurable precipitation is presented in Figure 2. In general, oil palm plant produced stemflow much larger than other plants for the same rainfall. Oil palm plant was capable of producing stemflow volume of 7-15 times compared with plants on forest land cover type, and reached 12-24 times of stemflow volume of rubber plants.

Stemflow yield vary both between different species and between the same species. These were consistent with the results of the study of Crockford and Richardson (2000), Garcia-Estringana et al. (2010), and Galdos et al. (2012). This variability may occur due to differences in rainfall, plant conditions, and meteorological conditions (Levia et al. 2010). Absolute value of stemflow is the influence of the relationship between rainfall duration, rainfall intensity, and characteristics of plants (Garcia-Estringana et al. 2010). The variability was caused by the difference among the biophysical characteristics of tree species, including the size of the canopy, leaf shape and orientation, angle branches, and bark roughness (Levia \& Herwitz 2005). The large volume of water flowing through the trunk will have an impact on water potential which is capable to infiltrate into the soil (Herwitz
1986). The greater water to the soil surface is the greater potential for water that can be infiltrated into the ground. Li et al. (2009) stated that stemflow is conducive to concentrate and keep the water in the deeper soil layers. Thus, if the water volume that reached the ground surface exceeds the infiltration capacity of the soil, water reaching the soil surface will be transformed into a run-off.

Stemflow depth Stemflow depth varied both on the same land cover type and among different land cover types (Table 1). Standard deviation results of stemflow depth data shows a great value, this means that the data have high variability. Results of paired t-test analysis showed that stemflows depth in forest and jungle rubber cover were significantly different. Stemflow depth in rubber plantation showed that R1, R2, and R5 were not significantly difference. R3 and R6 also were not significantly difference. Stemflow depth in oil palm plantation showed that OP2 and OP3 were not significantly difference.

Percentage of rainfall proportion as stemflow was not entirely depend on the diameter of the stem and canopy projection area (Figure 3), though there was a tendency that the larger stem diameter had the higher percentage of rainfall proportion as stemflow. R4 plants had large canopy projection area but smaller percentage of stemflow compared to other plants, while OP2 resulted in the largest stemflow. These results accorded with previous studies in which the average percentage of the stemflow was only $0.4 \%$ (Bahmani et al. 2012), 0.9-2.7\% (Park \& Cameron 2008), $0.1-1.5 \%$ (Molina \& del Campo 2012), and $0.3-1.4 \%$ in the natural tropical forests of Kalimantan (Asdak et al. 1998), so that in some analysis stemflow is often neglected.

However, the large volume of water generated by the stemflow must be taken into consideration of land management, especially of oil palm plantation. In oil palm 
plantion, the stemflow volume scale up to the ground surface was large enough to trigger the surface run-off. In the same area, the stemflow of the oil palm plantation was distributed only by a few plants because the plant density was lower than other land cover types that have higher trees density. Consequently, the rainwater reaching the soil surface through the stemflow in oil palm plantations was concentrated at fewer collection points.

Rainfall has a close relation with the depth of stemflow although this relation varies for each plant. Regression analysis relationship between rainfall depth and stemflow depth showed a tendency that the higher rainfall will increase the stemflow depth. The slope of the regression equation between rainfall depth and stemflow depth of oil palm plantation was much greater than logged forest, jungle rubber, and rubber plantation (Figure 4). This means that increasing of one unit of rainfall will lead to greater stemflow of oil palm plants than other plants.

The variability of stemflow depth were caused by the characteristic of canopy and stem. Variation in stemflow between species occurs because each plant has different
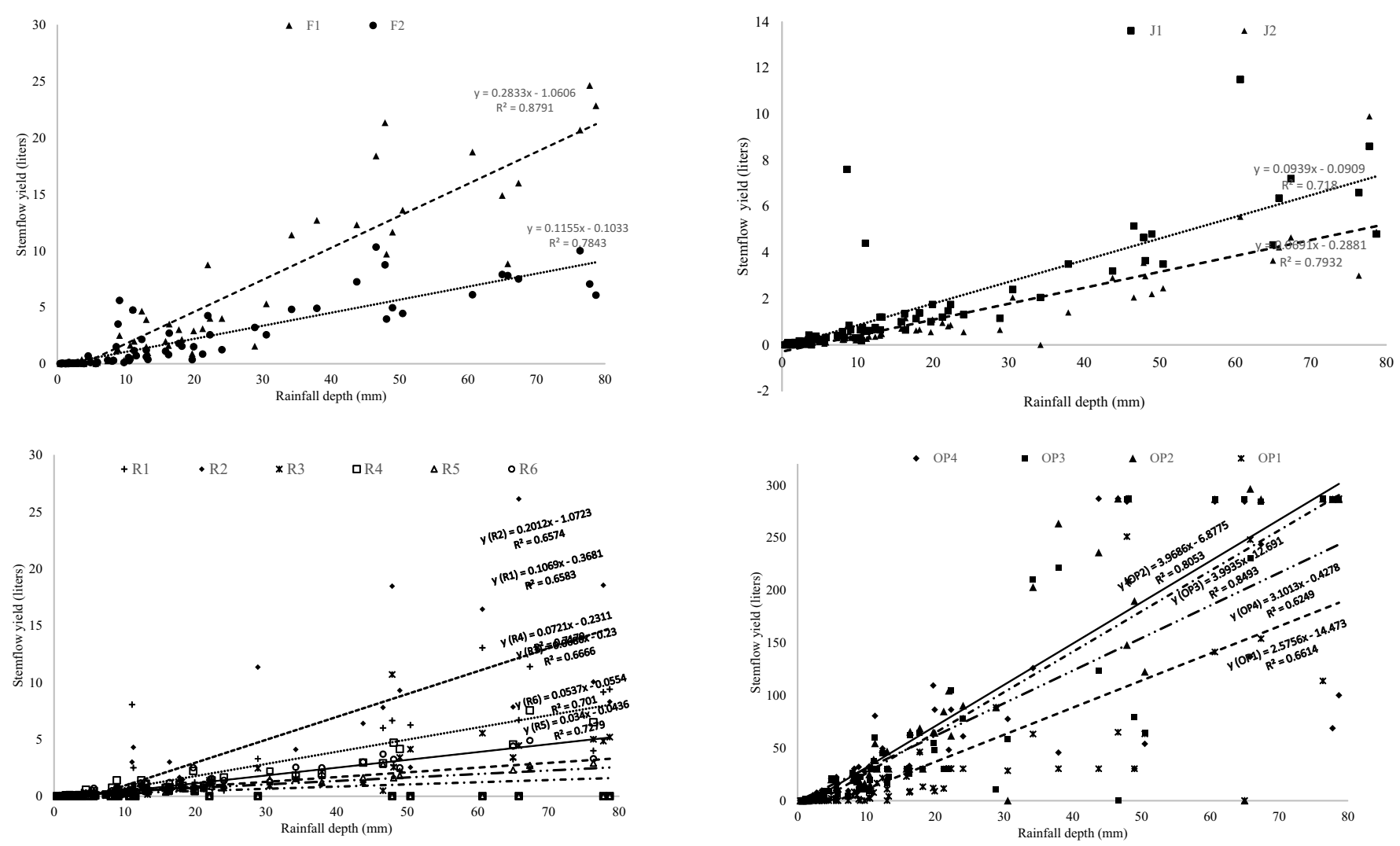

Figure 2 The results of stemflow volume measurements at each plant in every rainfall event.

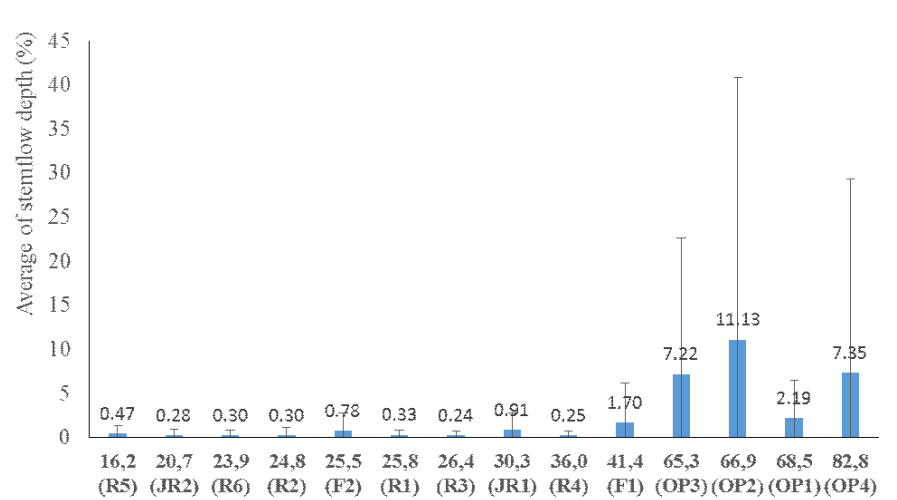

Stem Diameter (cm)

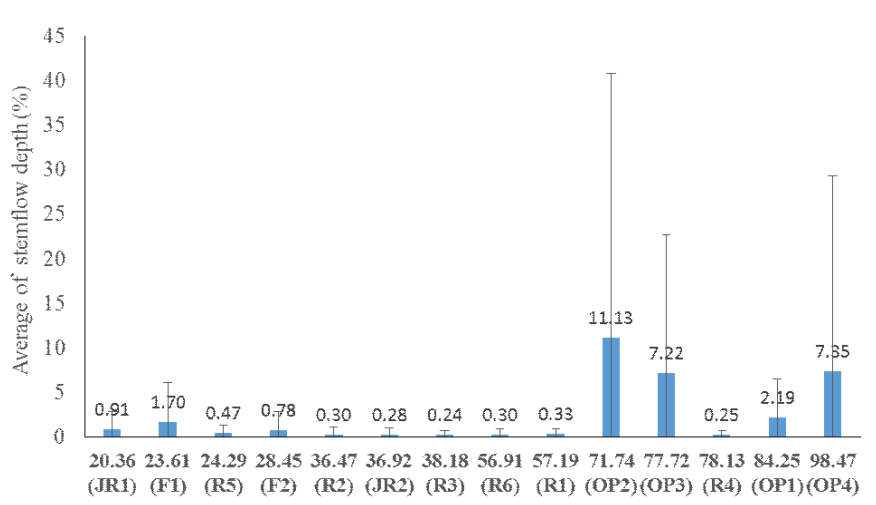

Canopy dianeter $(\mathrm{m} 2)$

Figure 3 The average of percentage of stemflow depth based on stem diameter and canopy diameter. 

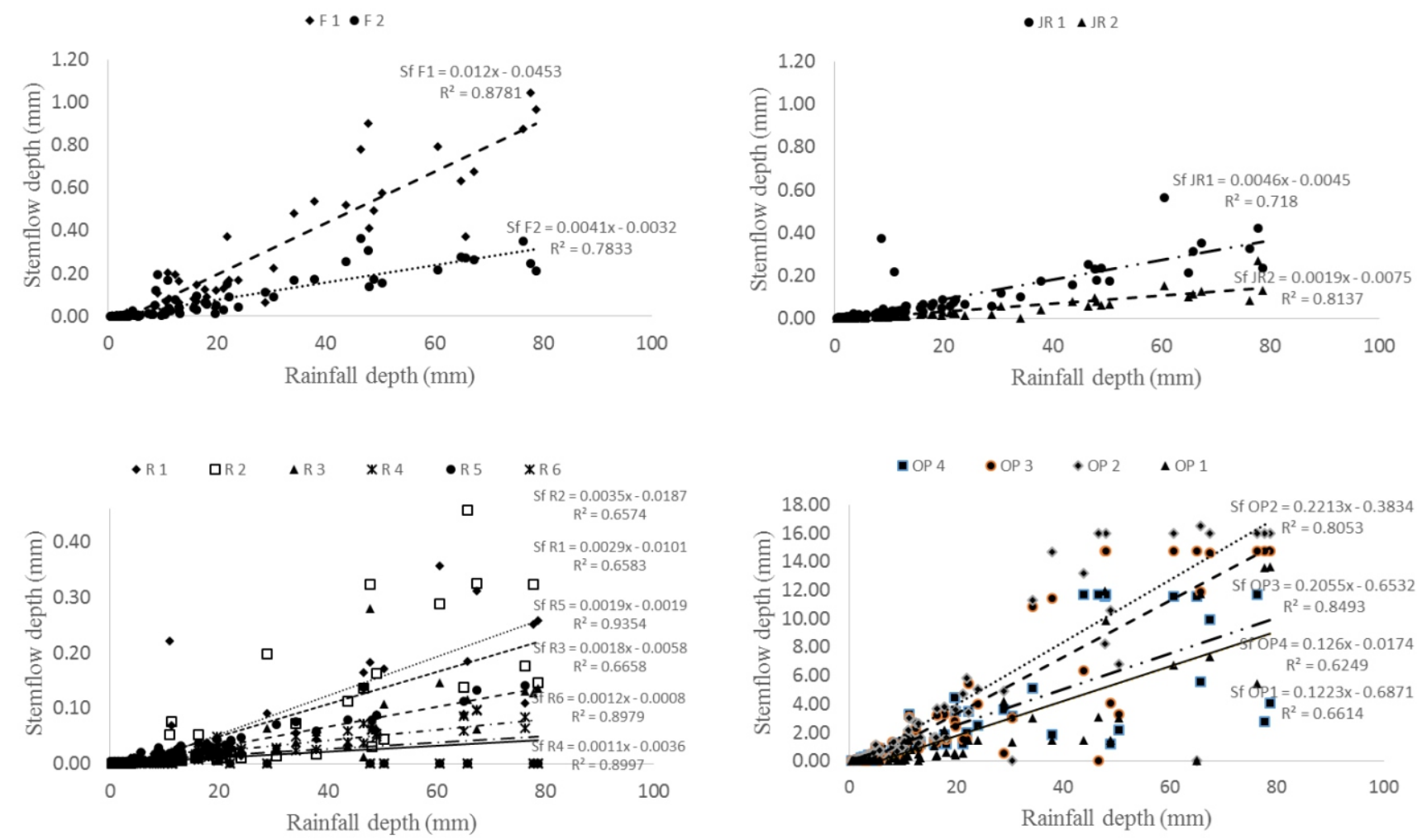

Figure 4 Regression relationship between rainfall depth $(\mathrm{mm})$ and stemflow depth based on canopy area.

characteristics (Návar 2011). This variation depends on the plant and its rainfall characteristics. The straight stem and smooth bark will increase more stemflow than the crooked and rough stem. The amount of stemflow was also closely related to the diameter or trees basal area. Previous research showed that the greater basal area has the greater stemflow (Asdak et al. 1998).

Stemflow rate Stemflow rate showed considerable variation both on the same land cover type and between different land cover types (Table 1). The average of stemflow rate at each plant are presented in Figure 5. Paired t-test analysis showed that there was a statistically significant difference between plants in forest cover and between plants in jungle rubber. Stemflow rate in a rubber plantation is quite diverse, there were certain plant groups that were not significantly different. Stemflow rate in oil palm plantation showed that OP2 and OP3 were not significantly difference but others were significantly difference. The largest stemflow rate occurred at the oil palm plantation, while the smallest one occurred in rubber plantation. Rainfall events with a depth of $1 \mathrm{~mm}$ produced stemflow volume of $7.17 \ell$ of oil palm plant, but only $0.73 \ell$ in rubber plant. The oil palm plant have stemflow rate far greater than the rubber plant. Figure 5 shows that the standard deviation of the measurement results of stemflow rate was greater than its average except in plants of OP2, OP3, and OP4; its mean that stemflow rate has high variability.
Stemflow funnelling ratio (SFR) The SFR calculation results is presented in Figure 6 and paired t-test analysis is presented in Table 1. The results showed that oil palm plant group has a SFR value which was much larger than other plants. The greatest SFR was found on oil palm plant namely OP2 as amount of 6.79 and the smallest SFR is in the rubber plant of R4 with magnitude of 0.52 . Plants of F1, R3, $\mathrm{R} 4$, and R6 have SFR average less than 1, indicates there is less water down to the stem becoming stemflow than rainfall on open area with equivalent diameter. SFR which is more than 1 indicates that the plant canopy drains water into the trunk. Paired t-test analysis showed that there was a statistically significant difference of SFR between plants in forest cover, however SFR in jungle rubber are not significantly difference. Stemflow rate in a rubber plantation showed that R1, R2, R5, and R6 were not significantly difference, while R3 and R4 were significantly difference. Stemflow rate in oil palm plantation showed that OP2 and OP3 were not significantly difference but others were significantly difference.

All fronds of oil palm canopy structure arranged toward the stem with shape of gutter like and its slope angle toward the trunk causes the bulk of the water from the canopy concentrating towards to the main stem. This resulted in the SFR of oil palm plant to be higher. In a big rainfall event, the effect of SFR is the concentration of rainfall in the stem bottom by stemflow mechanism, which in turn will increase the runoff coefficient (Charlier et al. 2009). The higher SFR 
means the higher distribution of rainfall to soil surface accumulating in around plant trunks. Rubber plant with the lowest average value of SFR indicated the least accumulation of water through the stemflow of the plant, while at the oil palm plant, the accumulation of water occurred at the base of the stem. SFR is calculated from the volume of stemflow without considering the canopy surface area that raises this volume and also without considering plant adaptation (Garcia-Estringana et al. 2010). This leads to SFR variability in the same plant species despite having almost similar trunk diameter. Návar (2011) stated that stemflow of water affects reception at ground level 2-7 times compared with the conditions of open ground. It is mainly on plants that have SFR value over 1 . Some other researchers reported varying SFR value of diverse plants in diverse environments (Carlyle-Moses \& Price 2006; Li et al. 2009)

Plant parameter Individual characteristics of plants measured in the form of type, stem diameter, basal area, canopy projection area, stem bark, and conditions are presented in Table 2. Table 1 and Table 2 show that stem characteristics and SFR did not show a clear relationship. The results of this study indicate that the palm trees with trunks rough conditions have a greater SFR compared with plants of forest cover with the same stem conditions but with smoother skin. On the contrary, the increasing bark thickness leads to absorption of water along stemflow pathways, reducing total stemflow volume (Levia \& Herwitz 2005). The combination of rough bark and angular fronds creates funnelling waterways and also disrupts stemflow in addition to providing habitat for lichen and epiphytes (Link et al. 2004) that can be found in oil palm stem, which also have large water storage capacities. Marin et al. (2000) reported that the relationship between physical characteristics and stemflow generation has been well documented in temperate forests, but contradictory results found in tropical forests.

Individual characteristics such as diverse plant can lead to variability in the results of stemflow. Canopy projection area associated with the surface area will capture rainwater that falls on the canopy. The higher extent of the canopy means the higher potential of rainwater that can be captured and flow through stem as stemflow. However, this study found that the canopy projection area was wider but the stemflow depth was lower than the plant with narrow canopy projection. This can be seen at stemflow depth of $\mathrm{R} 4$, whose canopy area was wider than R6, R1, OP2, and OP3 but its stemflow depth was lower (Figure 3 ). This is likely due to differences in density and thickness of the canopy. During the research, rubber plant shed leaves which resulted in canopy gaps, it reduced the capacity of canopy to retaining and flowing the rainfall to stem. Asdak et al. (1998) stated that stemflow correlated with physical characteristics such as tree diameter, basal area, and canopy projection area. Levia et al. (2010) stated that the difference in the size of tree trunks resulted effect on the outcome of the same species. Plants with large diameter are generally higher plants. Siles et al. (2010) suggested higher plants tend to have larger canopy projection area that can produce more stemflow volume. The results of this study indicate that the differences in plant characteristics such as stem diameter, basal area, canopy projection area, and trunks conditions produced various stemflow, however the relationship pattern between the stemflow and plant characteristics has not fully understood yet.

Although stemflow is almost always considered as a minor component of forest canopy water budgets as compared to interception and throughfall (Lorens \& Domingo 2007), vegetation with high SFR must be

Table 1 The average of stemflow parameters and the results of paired t test

\begin{tabular}{llll}
\hline \multicolumn{1}{c}{ Plant } & $\begin{array}{c}\text { Stemflow depth } \\
(\mathrm{mm})\end{array}$ & $\begin{array}{c}\text { Stemflow rate } \\
\ell \text { inm (rainfall) }\end{array}$ & Stemflow funnelling ratio \\
\hline F 1 & $0.18 \pm 0.27 \mathrm{a}$ & $0.13 \pm 0.13 \mathrm{a}$ & $0.95 \pm 0.93 \mathrm{a}$ \\
F 2 & $0.07 \pm 0.10 \mathrm{~b}$ & $0.08 \pm 0.10 \mathrm{~b}$ & $1.54 \pm 1.99 \mathrm{~b}$ \\
JR 1 & $0.08 \pm 0.12 \mathrm{~b}$ & $0.08 \pm 0.11 \mathrm{bc}$ & $1.07 \pm 1.49 \mathrm{ac}$ \\
JR 2 & $0.03 \pm 0.04 \mathrm{c}$ & $0.04 \pm 0.02 \mathrm{~d}$ & $1.15 \pm 0.72 \mathrm{abcd}$ \\
R 1 & $0.04 \pm 0.08 \mathrm{~d}$ & $0.06 \pm 0.09 \mathrm{bce}$ & $1.14 \pm 1.74 \mathrm{abcde}$ \\
R 2 & $0.05 \pm 0.09 \mathrm{~d}$ & $0.04 \pm 0.10 \mathrm{bcef}$ & $1.55 \pm 2.06 \mathrm{bcdf}$ \\
R 3 & $0.03 \pm 0.05 \mathrm{ce}$ & $0.05 \pm 0.04 \mathrm{efh}$ & $0.69 \pm 0.59 \mathrm{j}$ \\
R 4 & $0.02 \pm 0.02 \mathrm{f}$ & $0.03 \pm 0.02 \mathrm{degh}$ & $0.52 \pm 0.35 \mathrm{k}$ \\
R 5 & $0.03 \pm 0.03 \mathrm{~d}$ & $0.05 \pm 0.03 \mathrm{efh}$ & $1.61 \pm 0.77 \mathrm{befg}$ \\
R 6 & $0.02 \pm 0.02 \mathrm{ce}$ & $0.83 \pm 1.17 \mathrm{j}$ & $1.18 \pm 0.63 \mathrm{abcdefh}$ \\
OP 1 & $0.58 \pm 0.85 \mathrm{~g}$ & $2.38 \pm 1.71 \mathrm{i}$ & $2.24 \pm 3.18 \mathrm{bgh}$ \\
OP 2 & $0.76 \pm 1.18 \mathrm{~h}$ & $2.07 \pm 1.68 \mathrm{i}$ & $6.79 \pm 4.88 \mathrm{i}$ \\
OP 3 & $0.92 \pm 1.33 \mathrm{~h}$ & $2.33 \pm 1.75 \mathrm{i}$ & $6.20 \pm 5.02 \mathrm{i}$ \\
OP 4 & $0.39 \pm 0.80 \mathrm{i}$ & $4.33 \pm 3.251$ \\
\hline
\end{tabular}

Note : values followed by different letters indicate significant differences at $\alpha=0.05$ 
considered in land management to increase soil water recharge and to decrease runoff. Oil palm plantations have little litter cover on the soil surface, with a high SFR value it will increase runoff due to low soil infiltrability (Banabas et al. 2008). In forest cover, stemflow reaching the forest floor is intercepted by the litter, the remainder flows into the mineral soil as forest floor leachate and produce small runoff . Implication of land management that can be performed in the oil palm plantation to increasing soil water recharge is making rorak. The use of rorak can reduce runoff. Rorak is clogged holes of a certain size are made in the field and parallel to the contour lines. Rorak function is to trap and absorb water into the soil as well as accommodate the sediments. Rorak also serves to accommodate the remains of

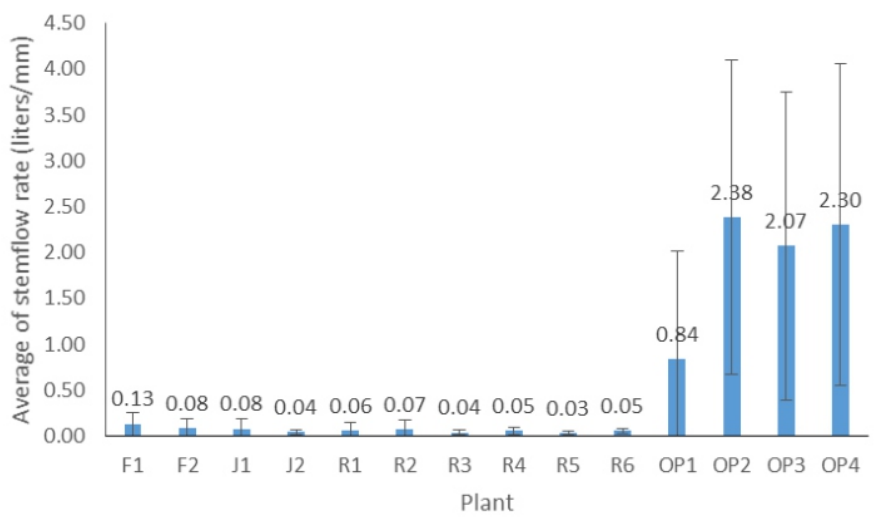

Figure 5 The average of stemflow rate at each plant. plants, such as weeds, pruned leaves or leaf litter.

\section{Conclusion}

The proportion of rainfall becomes stemflow various between $0.04-3.07 \%$ of the total rainfall that reaches the surface. The lowest percentage occured in the rubber and the largest in oil palm plantations. The mean volume of stemflow varies from $0.68 \ell$ in rubber (R5) until $64.53 \ell$ in oil palm (OP2). Stemflow depth varied both among the same plants and in a different land cover. Stemflow depth increased with the increase of rainfall. The slope of the regression relationship between rainfall and stemflow lowest depths found in rubber and the highest found in oil palm. Variability is also found in stemflow rate, where every $1 \mathrm{~mm}$ of rainfall

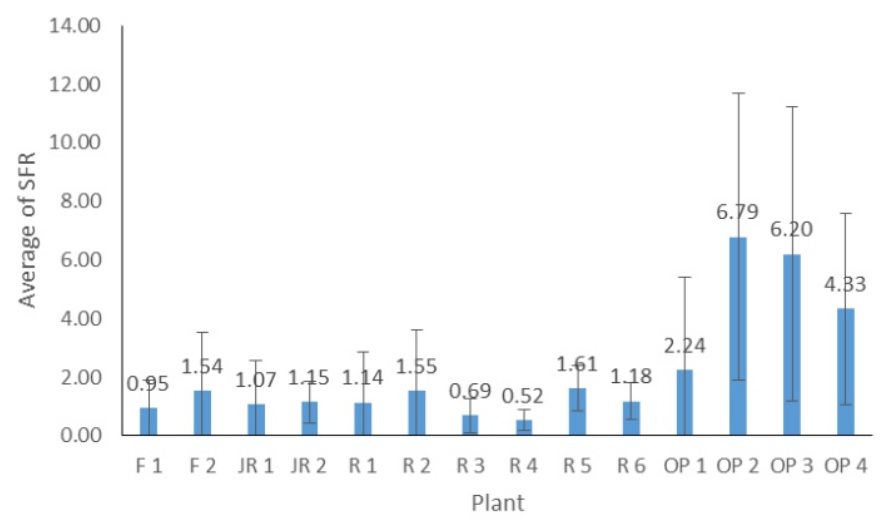

Figure 6 The results of SFR measurements at each plant.

Table 2 Plant characteristic of which stemflow was measured

\begin{tabular}{|c|c|c|c|c|c|c|c|}
\hline Land cover & $\begin{array}{c}\text { Tree/ } \\
\text { oil } \\
\text { palm }\end{array}$ & Species & $\begin{array}{l}\text { Dbh } \\
(\mathrm{cm})\end{array}$ & $\begin{array}{l}\text { Basal area } \\
\left(\mathrm{cm}^{2}\right)\end{array}$ & $\begin{array}{l}\text { Canopy } \\
\text { projection } \\
\text { area }\left(\mathrm{m}^{2}\right)\end{array}$ & Stem condition & $\begin{array}{c}\text { Stem bark } \\
\text { condition }\end{array}$ \\
\hline \multirow[t]{2}{*}{ Forest } & F1 & Litsea $\mathrm{sp}$. & 41.4 & 1,346 & 23.6 & Straight & Fine \\
\hline & $\mathrm{F} 2$ & Litsea $\mathrm{sp}$. & 25.5 & 5,100 & 28.5 & Straight & Fine \\
\hline \multirow{2}{*}{$\begin{array}{l}\text { Jungle } \\
\text { Rubber }\end{array}$} & JR1 & Hevea braziliensis & 30.3 & 721 & 20.4 & Rather slope & Rather rough \\
\hline & JR2 & Macaranga sp. & 20.7 & 336 & 36.9 & Bent & Fine \\
\hline \multirow{6}{*}{$\begin{array}{l}\text { Rubber } \\
\text { plantation }\end{array}$} & $\mathrm{R} 1$ & Hevea braziliensis & 25.8 & 523 & 36.5 & Slope & Rough \\
\hline & $\mathrm{R} 2$ & Hevea braziliensis & 24.8 & 482 & 57.2 & Straight & Rather rough \\
\hline & R3 & Hevea braziliensis & 26.4 & 547 & 38.2 & Bent & Rough \\
\hline & $\mathrm{R} 4$ & Hevea braziliensis & 36.0 & 1,017 & 78.1 & Straight & Rather rough \\
\hline & R5 & Hevea braziliensis & 16.2 & 206 & 24.3 & Rather slope & Rough \\
\hline & R6 & Archidendron pauciflorum & 23.9 & 448 & 56.9 & Bent & Fine \\
\hline \multirow{4}{*}{$\begin{array}{l}\text { Oil Palm } \\
\text { Plantation }\end{array}$} & OP1 & Elaeis guineensis Jacq & 68.5 & 3,680 & 84.3 & Straight & Rough \\
\hline & $\mathrm{OP} 2$ & Elaeis guineensis Jacq & 66.9 & 3,511 & 71.7 & Straight & Rough \\
\hline & OP3 & Elaeis guineensis Jacq & 65.3 & 3,346 & 77.7 & Straight & Rough \\
\hline & OP4 & Elaeis guineensis Jacq & 82.8 & 5,382 & 98.5 & Straight & Rough \\
\hline
\end{tabular}


can cause various stemflow between $0.73-7.17 \ell$ respectively on rubber tree and oil palm. SFR parameter also showed high variability both among plants at the same landcover and at the different landcover. The result showed that stemflow variability was influenced by rainfall factor and plant characteristic, even though the relationship between plant characteristic and stemflow has not fully understood yet. Although stemflow is almost always considered as a minor component of forest canopy water budgets as compared to interception and throughfall but vegetation with high SFR must consider in land management to increase soil water recharge and to decrease runoff.

\section{References}

Asdak C, Jarvis PG, Gardingen Pv, Fraser A. 1998. Rainfall interception loss in unlogged and logged forest areas of Central Kalimantan, Indonesia. Journal of Hydrology 206:237-244. http://dx.doi.org/10.1016/S00221694(98)00108-5.

Bahmani SMHG, Attarod P, Bayramzadeh V, Ahmadi MT, Radmehr A. 2012. Throughfall, stemflow, and rainfall interception in a natural pure forest of chestnut-leaved oak (Quercus castaneifolia C.A. Mey.) in the Caspian Forest of Iran. Annals of Forest Research 55(2):197-206.

Banabas M, Turner MA, Scotter DR, Nelson PN. 2008. Losses of nitrogen fertiliser under oil palm in Papua New Guinea: water balance, and nitrogen in soil solution and runoff. Australian Journal of Soil Research 46: 332-229. http://dx.doi.org/10.1071/SR07171.

Bäse F, Elsenbeer H, Neill C, Krusche AV. 2012. Differences in throughfall and net precipitation between soybean and transitional tropical forest in the southern Amazon, Brazil. Agriculture, Ecosystems and Environment 159:19-28. http://dx.doi.org/10.1016/j.agee.2012. 06.013 .

Broich M, Hansen MC, Potapov P, Adusei B, Lindquist E et al. 2011. Time-series analysis of multi-resolution optical imagery for quantifying forest cover loss in Sumatra and Kalimantan, Indonesia. International Journal of Applied Earth Observation and Geoinformation 13(2):277-291. http://dx.doi.org/10.1016/j.jag.2010.11.004.

Bryant ML, Bhat S, Jacobs JM. 2005. Measurements and modeling of throughfall variability for five forest communities in the southeastern US. Journal of Hydrology 312:95-108. http://dx.doi.org/10.1016/j. jhydrol.2005.02.012.

Carlyle-Moses DE, Laureano JSF, Price AG. 2004. Throughfall and throughfall spatial variability in Madrean oak forest communities of northeastern Mexico. Journal of Hydrology 297:124-135. http://dx.doi.org/10. 1016/j.jhydrol.2004.04.007.

Carlyle-Moses DE, Price AG. 2006. Growing-season stemflow production within a deciduous forest of southern Ontario. Hydrological Processes
20(17):3651-3663. http://dx.doi.org/10.1002/hyp.6380.

Charlier J-B, Moussa R, Cattan P, Cabidoche Y-M, Voltz M. 2009. Modelling run-off at the plot scale taking into account rainfall partitioning by vegetation: application to stemflow of banana (Musa spp) plant. Hydrology and Earth System Sciences Discussions 6:4307-4347. http://dx.doi.org/10.5194/hessd-6-4307-2009.

Crockford RH, Richardson DP. 2000. Partitioning of rainfall into throughfall, stemflow and interception: effect of forest type, ground cover and climate. Hydrological Processes 14(16-17):2903-2920. http://dx.doi.org/ 10.1002/1099-1085(200011/12)14:16/17<2903::AIDHYP126>3.0.CO;2-6.

Dasanto BD, Pramudya B, Boer R, Suharnoto Y. 2014. Effects of Forest Cover Change on Flood Characteristics in the Upper Citarum Watershed. Jurnal Manajemen Hutan Tropika 20(3):141-149. http://dx.doi.org/10. 7226/jtfm.20.3.141.

Dietz J, Holscher D, Leuschner C, Hendrayanto. 2006. Rainfall partitioning in relation to forest structure in differently managed montane forest stands in Central Sulawesi, Indonesia. Forest Ecology and Management 237:170-178. http://dx.doi.org/10.1016/j.foreco.2006. 09.044 .

Galdos FV, Álvarez C, García A, Revilla JA. 2012. Estimated distributed rainfall interception using a simple conceptual model and Moderate Resolution Imaging Spectroradiometer (MODIS). Journal of Hydrology 468-469:213-228. http://dx.doi.org/10.1016/j.jhydrol. 2012.08.043.

Garcia-Estringana P, Alonso-Blázquez N, Alegre J. 2010. Water storage capacity, stemflow and water funneling in Mediterranean shrubs. Journal of Hydrology 389:363-372. http://dx.doi.org/10.1016/j.jhydrol.2010. 06.017 .

Germer S, Elsenbeer H， Moraes JM. 2006. Throughfall and temporal trends of rainfall redistribution in anopen tropical rainforest, south-western Amazonia (Rondonia, Brazil). Hydrology and Earth System Sciences 10:383-393. http://dx.doi.org/10.5194/hess-10-3832006.

Germer S, Werther L, Elsenbeer H. 2010. Have we underestimated stemflow? Lessons from an open tropical rainforest. Journal of Hydrology 395:169-179. http://dx.doi.org/10.1016/j.jhydrol.2010.10.022.

He ZB, Yang JJ, Du J, Zhao WZ, Liu H, Chang XX. 2014. Spatial variability of canopy interception in a spruce forest of the semiarid mountain regions of China. Agricultural and Forest Meteorology 188:58-63. http://dx.doi.org/10.1016/j.agrformet.2013.12.008.

Herwitz SR. 1986. Infiltration-excess caused by stemflow in a cyclone-prone tropical rainforest. Earth Surface 
Processes and Landforms 11: 401-412. http://dx.doi.org/ 10.1002/esp.3290110406.

Hofhansl F, Wanek W, Drage S, Huber W, Weissenhofer A, Richter A. 2012. Controls of hydrochemical fluxes via stemflow in tropical lowland rainforests: Effects of meteorology and vegetation characteristics. Journal of Hydrology 452-453:247-258.

Komatsu H, Shinohara Y, Kume T, Otsuki K. 2008. Relationship between annual rainfall and interception ratio for forests across Japan. Forest Ecology and Management 256:1189-1197. http://dx.doi.org/10.1016/ j.foreco.2008.06.036.

Levia DF, Herwitz SR. 2005. Interspecific variation of bark water storage capacity of three deciduous tree species in relation to stemflow yield and solute flux to forest soils. Catena 64(1):117-137. http://dx.doi.org/10.1016/ j.catena.2005.08.001.

Levia DF, Van Stan II JT, Mage SM, Kelley-Hauske PW. 2010. Temporal variability of stemflow volume in a beech-yellow poplar forest in relation to tree species and size. Journal of Hydrology 380:112-120. http://dx.doi. org/10.1016/j.jhydrol.2009.10.028.

Llorens P, Domingo F. 2007. Rainfall partitioning by vegetation under Mediterranean conditions. A review of studies in Europe. Journal of Hydrology 335(1-2):37-54. http://dx.doi.org/10.1016/j.jhydrol. 2006.10.032.

Li X, Niu J, Xie B. 2014. The effect of leaf litter cover on surface runoff and soil erosion in Northern China. PLoS ONE 9(9):e107789. http://dx.doi.org/10.1371/journal. pone. 0107789 .

Li XY, Yang ZP, Li YT, Lin H. 2009. Connecting ecohydrology and hydropedology in desert shrubs: stemflow as a source of preferential flow in soils. Hydrology and Earth System Sciences 13(7): 1133-1144. http://dx.doi.org/10.5194/hess-13-1133-2009.

Link TE, Unsworth M, Marks D. 2004. The dynamics of rainfall interception by a temperate seasonal rainforest. Agricultural and Forest Meteorology 124 (3-4):171-191. http://dx.doi.org/10.1016/j.agrformet. 2004.01.010.

Marin CT, Bouten W, Sevink J. 2000. Gross rainfall and its partitioning into throughfall, stemflow and evaporation of intercepted water in four forest ecosystems in western Amazonia. Journal of Hydrology 237 (1-2): 40-57. http://dx.doi.org/10.1016/S0022-1694(00)00301-2.

Miyamoto M. 2006. Forest conversion to rubber around Sumatran villages in Indonesia: Comparing the impacts of road construction, transmigration projects and population. Forest Policy and Economics 9(1):1-12. http://dx.doi.org/10.1016/j.forpol.2005.01.003.
[MoA] Ministry of Agriculture. 2012. Basis Data Statistik Pertanian. http://aplikasi.deptan.go.id/bdspnewlok. asp.[3 Mei 2012]

Molina AJ, del Campo AD. 2012. The effects of experimental thinning on throughfall and stemflow: A contribution towards hydrology-oriented silviculture in Aleppo pine plantations. Forest Ecology and Management 269:206-213. http://dx.doi.org/10.1016/j.forpol.2005. 01.003 .

Návar J. 2011. Stemflow variation in Mexico's northeastern forest communities: Its contribution to soil moisture content and aquifer recharge. Journal of Hydrology 408:35-42. http://dx.doi.org/10.1016/j.jhydrol. 2011.07.006.

Nieschulze J, Erasmi S, Dietz J, Hölscher D. 2009. Satellitebased prediction of rainfall interception by tropical forest stands of a human-dominated landscape in Central Sulawesi, Indonesia. Journal of Hydrology 364(3-4):227-235. http://dx.doi.org/10.1016/j.jhydrol. 2008.10.024.

Noeralam A, Arsyad S, Iswandi A. 2003. Effective technique of run off control on sloping upland farming. Jurnal Tanah dan Lingkungan 5 (1): 13-16.

Opakunle JS. 1989. Throughfall stemflow and rainfall interception in a cacao plantation in south western Nigeria. Tropical Ecology 30(2):244-252.

Park A, Cameron JL. 2008. The influence of canopy traits on throughfall and stemflow in five tropical trees growing in a Panamanian plantation. Forest Ecology and Management 255:1915-1925. http://dx.doi.org/10. 1016/ j.foreco.2007.12.025.

[PT. Asiatic Persada] 2013. Analisis Dampak Lingkungan (AMDAL) Addendum Peningkatan Kapasitas Pabrik Kelapa Sawit dari 42 Ton TBS/Jam menjadi 60 Ton TBS/Jam PT Asiatic Persada di Kecamatan Bajubang Kabupaten Batanghari Jambi. Jambi: PAPersada.

Romijn E, Ainembabazi JH, Wijaya A, Herold M, Angelsen A, Verchot L, Murdiyarso D. 2013. Exploring different forest definitions and their impact on developing REDD+ reference emission levels: A case study for Indonesia. Environmental Science \& Policy 33:246-259. http://dx.doi.org/10.1016/j.envsci. 2013.06.002.

Sharma P, Rai SC. 2004. Streamflow, sediment and carbon transport from a Himalayan watershed. Journal of Hydrology 289(1-4): 190-203. http://dx.doi.org/10. 1016/j.jhydrol.2003.11.023.

Shachnovich Y, Berliner PR, Bar P. 2008. Rainfall interception and spatial distribution of throughfall in a pine forest planted in an arid zone. Journal of Hydrology 349:168-177. http://dx.doi.org/10.1016/j.jhydrol. 2007.10.051. 
Siles P, Vaast P, Dreyer E, Harmand J-M. 2010. Rainfall partitioning into throughfall, stemflow and interception loss in a coffee (Coffea arabica L .) monoculture compared to an agroforestry system with Inga densiflora. Journal of Hydrology 395:39-48. http://dx.doi. org/10.1016/j.jhydrol.2010.10.005.

Uber M, Levia DF, Zimmermann B, Zimmermann A. 2014. The influence of tree morphology on stemflow generation in a tropical lowland rainforest. Geophysical Research Abstracts 16: EGU2014-2110.

Zhang M, Wei X, Sun P, Liu S. 2012. The effect of forest harvesting and climatic variability on runoff in a large watershed: The case study in the Upper Minjiang River of Yangtze River basin. Journal of Hydrology
464-465:1-11. http://dx.doi.org/10.1016/j.jhydrol. 2012.05.050.

Ziegler AD, Giambelluca TW, Nullet MA, Sutherland RA, Tantasarin C, Vogle JB, Negishi JN. 2009. Throughfall in an evergreen-dominated forest stand in northern Thailand: Comparison of mobile and stationary methods. Agricultural and Forest Meteorology 149:373-384. http://dx.doi.org/10.1016/j.agrformet.2008.09.002.

Zimmermann A, Germer S, Neill C, Krusche AV, Elsenbeer H. 2008. Spatio-temporal patterns of throughfall and solute deposition in an open tropical rain forest. Journal of Hydrology 360:87-102. http://dx.doi.org/10.1016/j. jhydrol.2008.07.028. 